\title{
RESEARCH NOTE \\ Different alternatives for producing sprouts of avocado (Persea americana) rootstocks
}

\author{
Mónica Castro, Claudia Fassio, Nicole Darrouy, Marcela Aedo, and Lorena \\ Jorquera \\ Facultad de Agronomía, Pontificia Universidad Católica de Valparaíso. Casilla 4-D, Quillota, Chile.
}

\begin{abstract}
M. Castro, C. Fassio, N. Darrouy, M. Aedo, and L. Jorquera. 2011. Different alternatives for producing sprouts of avocado (Persea americana) rootstocks. Cien. Inv. Agr. 38(2): 219-226. In Chile, most avocado orchards have been planted using 'Hass' as the scion variety on seedling rootstocks. This has led to the presence of a large variety of individuals, some of which show, among other characteristics, high productivity and a low degree of biennial bearing cycle in the same growing conditions. The most common method used in other countries to propagate such rootstocks from trees involves severe topping; however, this technique is notably destructive, making it difficult to employ in commercial orchards. With the goal of developing alternate methods for forcing shoot production from the rootstock, we tested two different procedures in July 2002 and March 2003, respectively: wounding in conjunction with the application of $1.1 \mathrm{M}$ or $2.2 \mathrm{M}$ benzylaminopurine (BAP) and the removal of one half of the tree canopy (on a vertical plane) and girdling (at widths of 2 or $5 \mathrm{~mm}$ ). The results indicate that, by removing the top layer of the soil, wounding and applying the BAP spray (1.1 M in July), it is possible to force the production of epicormic or basal sprouting from the rootstock. Additionally, vigorous shoots were obtained on both evaluation dates through the removal of half of the canopy or through girdling.
\end{abstract}

Keywords: Avocado, basal sprout, cloning, cytokinin, epicormic sprout, girdling, rootstock.

\section{Introduction}

The avocado industry (Persea americana Mill.) is based principally on seedling rootstocks (Ben-Ya'acov and Michelson, 2002). Most Chilean plantations are founded on Mexican rootstocks. This material has been used mainly because of its ease and speed of propagation, as

Received March 5, 2010. Accepted May 19, 2011.

Corresponding author: mcastro@ucv.cl well as the price of the plant. Each rootstock obtained is genetically different, as avocado seeds are heterozygotic (Ben-Ya'acov and Michelson, 2002). These differences in rootstocks produce different habits in growth and fruiting, as well as different levels of susceptibility to the bioantagonists and environmental factors present in Chile (Castro et al., 2003); however, certain ecotypes may be determined to be outstanding in the presence of a particular limiting condition.

In order to select outstanding ecotypes at the orchard level, aerial vegetal material is collected 
and subsequently propagated vegetatively by grafting; however, the properties pertaining to the rootstock to the variety are not retrieved with this method. Bijzet and Sippel (2001) demonstrated that differences in the behavior and productivity traits observed in individual cultivars grafted on the same rootstock may be due to the different relationships established in each graftrootstock combination. Research conducted in Israel by Ben-Ya'acov et al. (1992) and in Spain by Barceló Muñoz et al. (1999) pertaining to the selection of outstanding rootstocks indicated that the induction of sprouting in rootstocks by total tree removal under the joint was possible after selection of the candidate trees and that material for propagation could accordingly be obtained. It is, however, necessary to mention that this technique is highly destructive because the whole aerial part of the tree is eliminated.

Gordon et al. (2006) pointed out the existence of axilar buds in the trunk of most angiosperms and gymnosperms, which are known as dormant, latent or epicormic buds and are inactive for years. The presence and number of such buds varies throughout the life of the tree; however, older trees have a higher number of epicormic sprouts per trunk area than do younger trees, although they tend to sprout less frequently, due to such mechanical considerations as bark thickness or failures in the vascular connections of the plant.

Studies in forest species have determined that the production of epicormic sprouts is stimulated or increased by light, heat, hormonal stimuli, or a combination of these factors (Zimmermann and Brown, 1971; Collier and Turnblom, 2001; Deal et al., 2003). Takiya et al. (2010) determined that pruning was a tool that allowed increasing light intensity under the canopy, thereby increasing the length and development of epicormic sprouts in Japanese larch. Similarly, Gordon et al. (2006) concluded that the pruning season represents one of the most important factors in epicormic sprout production in peaches.

Likewise, Smith et al. (1993) obtained rootstock sprouts by exposing the roots of avocado trees to sunlight and girdling, leading to the cloning of five trees that proved to be outstanding in production. Another alternative used in avo- cado propagation is the proliferation of in vitro sprouts by the use of cytokinin. González et al. (1990) increased the number of sprouts from avocado embryos cultivated in vitro by adding kinetin to the culture medium.

There is a need to develop less destructive techniques for the clonal propagation of rootstocks to obtain vegetal material identical to the parental material and to evaluate the vegetal material's long-term characteristics. The present research aimed to develop use cytokinins, pruning, and girdling to achieve the basal renewal of rootstocks in outstanding avocado trees planted in fields.

\section{Materials and methods}

The trials were conducted in an avocado orchard of the Experimental Station La Palma of the Faculty of Agronomy of Pontificia Universidad Católica de Valparaíso, which is located in the Province of Quillota, Region of Valparaíso, Chile (32 $53^{\prime} 38,69^{\prime \prime} \mathrm{S}$ and $\left.71^{\circ} 12^{\prime} 15,78^{\prime \prime} \mathrm{W}\right)$. The zone has a local Mediterranean climate that is characterized by a dry period in the warm season and rains in the cold season. The region has an annual mean temperature $\left(15.3{ }^{\circ} \mathrm{C}\right)$, with a maximum mean temperature in the warmest month (January, $27{ }^{\circ} \mathrm{C}$ ) and a minimum mean temperature of coldest month (July, $5.5^{\circ} \mathrm{C}$ ). The annual precipitation is $437 \mathrm{~mm}$ with June as the rainiest month $(125 \mathrm{~mm})$. The dry season lasts for eight months. The soil is 50 to $70 \mathrm{~cm}$ deep with a water level of 70-90 cm, loam clay texture on the surface, variable stone cover, plain topography, slow permeability and deficient-topoor drainage (Ciren, 1985).

This study was conducted in two periods: 2002-2003 and 2003-2004. In the first period, the trials began in July with photosynthetically active incident radiation (PAR) at $30 \mathrm{~cm}$ of 8.8 $\mu \mathrm{mol} \mathrm{m}-{ }^{2}$ seg $^{-1}$ trunk. In the second period, during the month of March, an incident PAR at 30 $\mathrm{cm}$ of $35 \mu \mathrm{mol} \mathrm{m}^{-2} \mathrm{seg}^{-1}$ trunk was recorded. The incident PAR was measured using a LI-COR data logger (model LI-1400, Lincoln, U.S.A.). Seven-year-old avocado trees were evaluated in both stages, and the cultivar 'Hass' was grafted 
in Mexican rootstocks and irrigated by micro sprinkler with healthy and homogeneous aerial development trees. Two trials were conducted during those periods, consisting of three treatments each with three repetitions on three trees.

In measurements made every 15 days to determine the presence or absence of sprouting, any growth of at least $1 \mathrm{~cm}$ was identified as a sprout. Length and diameter measurements (cm) for each sprout were obtained once a week using a digital vernier Mitutoyo (code $\mathrm{N}^{\mathrm{0}} 500$ 144, 0001325 series, Japan). The treatments administered in both periods are described below.

\section{Test 1. Effect of wounding and cytokinin application on collar sprouting}

Tree trunks were ablaqueated, removing the soil around the collar for exposure. Treatments were administered, which involved wounding in combination with the benzylaminopurine application (BAP, Sigma) at a concentration of 1.1 $\mathrm{M}$ (T1), wounding in combination with BAP at a concentration of $2.2 \mathrm{M}$ (T2), and a control treatment (T0). The wounding was done in oblique cuts using a Bahco saw along the trunk's circumference in the exposed zone without overlaps between cuts to a depth of to $0.5 \mathrm{~cm}$ (only the bark was compromised) separated by 10 $\mathrm{cm}$. The BAP application was made with a $1 \mathrm{~L}$ manual duster with a total amount of $250 \mathrm{~mL}$ of solution applied.
Test 2. The stimulating effects of pruning and girdling on sprouting from the trunk

The main east-oriented branch was pruned with a model 0.80 chainsaw, leaving $20 \mathrm{~cm}$ free to ensure that light reached the basal zone. The incident PAR with this treatment increased by $25 \%$ inside the canopy. The treatments applied were as follows: pruning plus $0.2 \mathrm{~cm}$ girdling (T1), pruning plus $0.5 \mathrm{~cm}$ girdling (T2), and the control (T0). The girdling in treatments $\mathrm{T} 1$ and T2 were made with a Bahco saw at $5 \mathrm{~cm}$ below the graft joint. It should be noted that this intervention was made only on the pruned branch side and not along the entire trunk perimeter.

The results obtained were analyzed with the statistical software package SPSS 16.0 using the $\chi^{2}$ test.

\section{Results}

The results obtained in the two tests and the two periods evaluated are presented in Table 1. Despite the absence of a statistical effect on the sprouting among the different tests and treatments, there was sprouting in the rootstock zone in the test with wounding and application of cytokinins (1.1 M) in the 2002-2003 period, as well as in the second test with the pruning and 2-mm girdling (in both periods) and 5-mm girdling (only in the first period).

Table 1. The effect of treatments to achieve sprouting for clonal propagation from basal renewals in avocado rootstocks during two periods of assessment (sprouting observed/number of repetitions).

\begin{tabular}{llll}
\hline & Treatments & Sprouting & $\begin{array}{l}\text { Sprouting } \\
2003-2004\end{array}$ \\
\hline $\begin{array}{l}\text { Test 1 } \\
\text { Application of cytokinins and incision }\end{array}$ & Control & $2002-2003$ & $0 / 3$ \\
& incision+ BAP 1.1 M & $0 / 3$ & $0 / 3$ \\
& incision+ BAP 2.2 M & $1 / 3$ & $0 / 3$ \\
Test 2 & Control & $0 / 3$ & $0 / 3$ \\
Pruning and girdling & Girdling 2 mm & $0 / 3$ & $2 / 3$ \\
& Girdling 5 mm & $1 / 3$ & $0 / 3$ \\
$\chi 2$ & & $1 / 3$ & 0.369 \\
\hline
\end{tabular}

Contingency chi-square $\left(\chi^{2}\right)$ analysis $(\mathrm{df}=4)$. 
The effect of wounding and the cytokinin application on collar sprouting

One of the trees treated with wounding and BAP application $(1.1 \mathrm{M})$ during the first period of study showed the presence of two sprouts, one northward and another eastwards, 74 days after the treatment in early spring. Both sprouts were green and well-aspected, which were features that remained consistent during the entire measurement period (Figure 1). They also showed growth activity, exceeding a length of $3 \mathrm{~cm}$ after 42 days and reaching diameter values of 0.6 and $0.5 \mathrm{~cm}$ after 56 days in each case.

The stimulating effect of pruning and girdling on sprouting from the trunk

During the first period, a response was observed 89 days after the treatments in October, when one of the trees was removed and 5-mm girdlings (T2) showed the presence of sprouts. After 15 additional days, a sprout was observed in one of the trees removed and with 2-mm girdlings (T1). During the second period of study, the same treatment showed sprouting in dif- ferent trees at 112 and 133 days (Figure 2). It should be noted that one of these trees showed the presence of sprouts again at 207 days after the treatment.

\section{Discussion}

The effect of wounding and cytokinin application on collar sprouting

It is well known that the sprouting process is affected by growth regulators, among which cytokinins play an important role. Taiz and Zeiger (1998) showed that their synthesis occurs mainly in the roots, and that they are involved in cell division, proliferation of axilar buds, and delayed leaf senescence, among other processes. Gordon et al. (2006) confirmed the consensus that hormones exert an impact on the sprouting of epicormic buds. The sprouts obtained in this test were consistent with reports by PliegoAlfaro et al. (1987) in which the development of axilar buds in the in vitro culture of nodal avocado segments was achieved in a medium supplemented with benzyladenine. Similarly, Barceló-Muñoz et al. (1999) used benzyladenine to induce the proliferation of juvenile and adult avocado material.

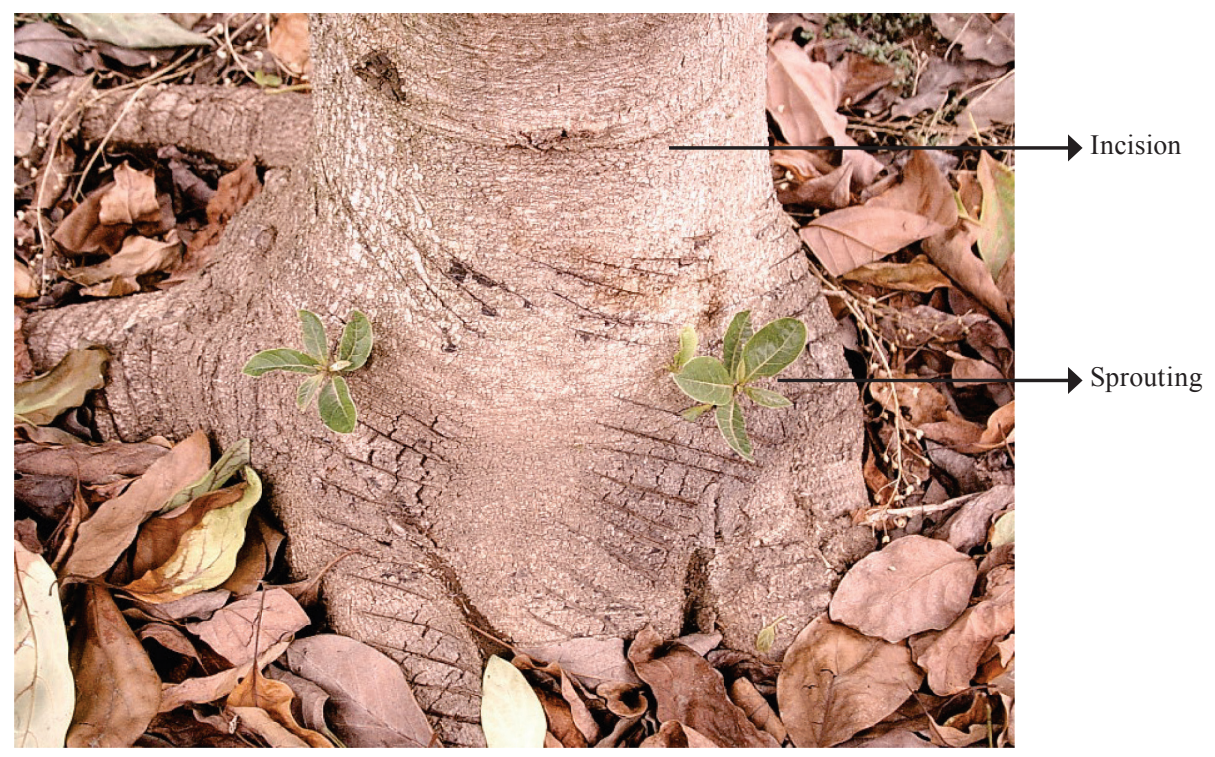

Figure 1. Basal renewals of avocado rootstocks obtained by removal from the basal portion through incision and application of benzylaminopurine 1.1 M, as implemented in July 2002. 


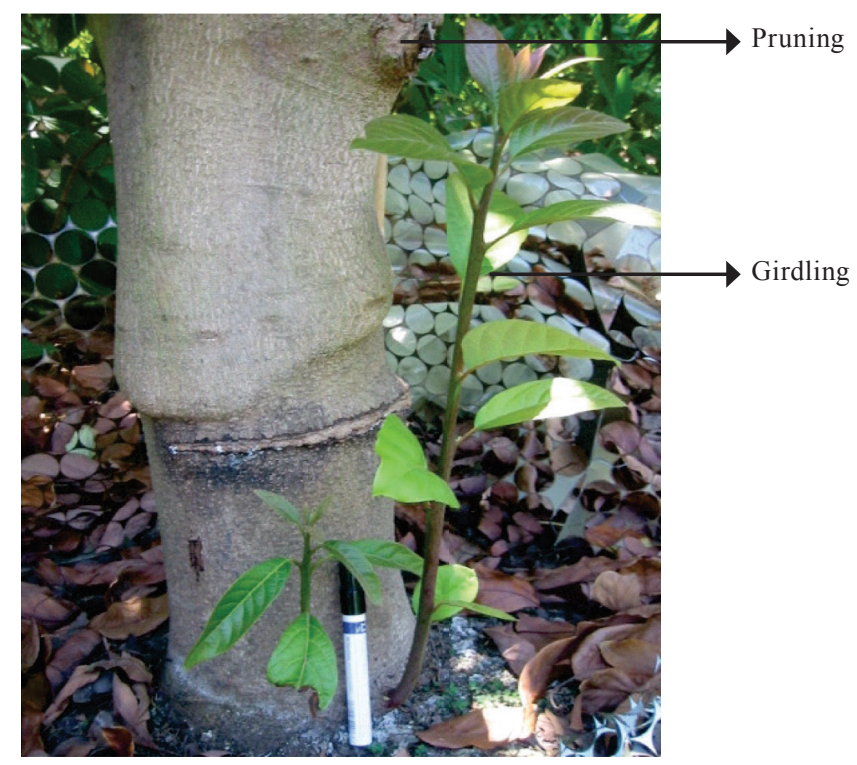

Figure 2. Basal renewals of avocado obtained by pruning and girdling $(2 \mathrm{~mm})$ the rootstocks in March 2003.

Tapia (1993) observed that avocados in the region of Quillota (Chile) begin a period of vegetative growth on August 31 that extends until January 19. The sprouting observed in this test falls on this aforementioned period. Additionally, there is the positive action that sunlight exerts on the vegetative growth (Gil-Albert, 1992), which is achieved by removing soil from the trees' trunks and exposing some of the principal roots to the insolation effect.

Sprouting was absent in all of the treatments applied during the second period of study. The shade offered by the trees' canopies appeared to be play an important role, as it hindered the penetration of direct light to the exposed section, which is necessary for accelerating sprouting (Smith et al., 1993). At the same time, according to Tapia (1993), avocado trees showed an increase in the rate of radicular growth on March 17, which subsequently decreased before ending on May 13. This probably affects the sprouts' development, given the competitive relationship between root growth and vegetative growth.

The stimulating effect of pruning and girdling on sprouting from the trunk

The results obtained in these tests resonate with Ben-Ya'acov and Michelson (1995), who point out that the Mexican rootstocks exhibit an easier sprout emission in fields than do Guatemalan rootstocks. In all of the treatments where sprouting was obtained, the sprout was below the girdling, which was used in this test as a restrictive measure, as some circulation of phytohormones and carbohydrates (Whiley, 2002) toward the roots is interrupted with this practice. This finding is particularly supported by the characteristics of auxins, which circulate basipetally and are synthesized in apexes, stems and leaves (Taiz and Zeiger, 1998). On the other hand, cytokinins are mainly synthesized in roots and are extended through the plant by the xylem. Therefore, the auxin concentration below the girdling is lower, and a higher cytokinins proportion might be promoting the buds' differentiation toward the basal sector of the tree (i.e., toward the pruned zone) and additionally allowing light penetration. This notion is consistent with results obtained by Smith et al. (1993) and Durand (1990), which used girdling as a technique to obtain sprouts in a rootstock.

The sprouts obtained during July (winter) showed a lower accumulated growth (reaching 7.8 and $1.6 \mathrm{~cm}$ long) in comparison with the sprouts obtained in October (which reached 67.4, 34.2 and $40.5 \mathrm{~cm}$, in chronological order of detection). This finding was measured at 56 days of growth, 
when optimal temperatures of vegetative growth occur (between 20 and $26{ }^{\circ} \mathrm{C}$ in avocado, depending on the phenological stage and cultivar; Ciren-Corfo, 1989). These results are consistent with the studies made by Gordon et al. (2006) in peaches. They described the importance of pruning season, which affects both sprouting and the further growth of the epicormic sprouts, which, in turn, might be related to the carbohydrate reserves present in the tree. These researchers determined an increasing and significant correlation between the content of non-structural carbohydrates in the bark and the dry weight of the epicormic sprouts. On the other hand, the responses of the trees to the pruning and girdling treatments $(5 \mathrm{~mm})$ made in July was the absence of sprouting, which may be due to overly drastic girdling, which led to a diminished flow of carbohydrates toward the basal portion.

The sprouting obtained in July 2003 may be related to the second flash of radicular avocado growth (Tapia, 1993). Considering that roots are an organ of cytokinin production, a higher concentration of these growth regulators in the plant might stimulate the processes of cell division and organogenesis involved in sprouting. Additionally, it has been observed that severe pruning encourages extensive sprouting, especially in the zones receiving increased light penetration (Collier and Turnblom, 2001; Deal et al., 2003). The studies made by Takiya et al. (2010) indicated the importance of light intensity under the canopy on the development of cypress sprouts, concluding that this parameter should define the level of pruning severity for the production of these sprouts. This finding suggests that different aspects of pruning management, such as the season during which and the intensity with which they are performed, could have an important effect on epicormic sprouts' production.

As such, sprouting induction of an avocado rootstock might be possible through the removal of the trunk, wounding, and the application of $1.1 \mathrm{M}$ benzylaminopurine in July. Likewise, both the lateral removal of the main branch, ensuring light penetration, and the girdling of the trunk to $2 \mathrm{~mm}$ in March and July, as well as similar branch removal and 5-mm girdling in July, also promote rootstock sprouting.

The results obtained in this study are strongly related to prevailing environmental conditions and the growth phenology of the species in question, which determines sprout growth. The phenology of avocado and, more specifically, the flushes of vegetative growth, also affect the appearance and vigor of the rootstock sprouts. Conversely, it is noteworthy that the material used in these experiments derives from the seed. As such, the potential production of epicormic sprouts must vary, depending on their higher or lower capacity for starch accumulation. Studies made by Pernice et al. (2006) and Gordon et al. (2006) in peaches indicate the importance of reserves stored in the trunk and roots by the rootstocks for the production of these types of sprouts.

\section{Resumen}

M. Castro, C. Fassio, N. Darrouy, M. Aedo y L. Jorquera. 2011. Evaluación de diferentes alternativas para la producción de brotes de palto (Persea americana). Cien. Inv. Agr. 38(2): 219-226. En Chile, la mayoría de los huertos de palto (Persea americana Mill.) sobre los cuales se encuentra el injerto 'Hass' están sobre portainjertos provenientes de semilla. La influencia de las características propias del portainjerto ha dado como resultado la existencia de una amplia variedad de individuos con distintos niveles de producción y alternancia en iguales condiciones de crecimiento. En otros países, se han desarrollado técnicas como la poda completa del árbol para la clonación de portainjetos, sin embargo esta técnica es altamente destructiva y difícil de implementar en huertos comerciales. Por esta razón se desarrolló una metodología, con el 
objetivo de obtener brotación de brotes epicórmicos o renuevos basales desde el portainjerto, en dos épocas distintas (julio y marzo, durante los años 2002 y 2003, respectivamente), a través del lesionado y la aplicación de bencilaminopurina (BAP) en dos concentraciones $(1,1$ y 2,2 M) y rebaje parcial del árbol y anillado (de 2 y $5 \mathrm{~mm}$ ). Los resultados obtenidos mostraron que mediante el lesionado y aplicación de BAP 1,1 M en julio, se obtuvieron brotes epicórmicos o basales desde la zona del portainjerto; al podar parcialmente el árbol; y que al anillar se logra obtener brotes vigorosos en ambas épocas de evaluación.

Palabras clave: Anillado, brotes basales, brotes epicórmicos, citocininas, clonación, palto, portainjerto.

\section{References}

Barceló-Muñoz, A. C. Encina, E. Simón-Pérez, and F. Pliego-Alfaro. 1999. Micropropagation of adult avocado. Plant Cell, Tissue and Organ Culture 58: 11-17.

Ben-Ya'acov, A., E. Michelson, M. Zilberstaine, Z. Barkan, and I. Sela. 1992. Selection of clonal avocado rootstocks in Israel for high productivity under different soil conditions. In: Proceeding of Second World Avocado Congress. California. April 21-26. 1991. p. 521-526.

Ben-Ya'acov, A., and E. Michelson. 1995. Avocado rootstocks. Horticultural Reviews 17:381-429.

Ben-Ya'acov, A., and E. Michelson. 2002. Portainjertos de aguacate. In: Seminario Internacional: Selección y uso de portainjertos y nuevas variedades de aguacate. Pontificia Universidad Católica de Valparaíso. Facultad de Agronomía. Quillota, Chile. 3 diciembre 2002. p. 1-60.

Bijzet, Z., and A.D. Sippel. 2001. Rootstocks. In: The cultivation of avocado. Institute for Tropical and Subtropical Crops ARC-LNR. Dynamic Ad. p. $85-103$

Castro M., C. Fassio, N. Darrouy, and A. BenYa'acov. 2003. Determinación de rangos de variabilidad en los niveles de producción del cultivar 'Hass' sobre portainjertos de semilla de raza Mexicana en Chile. In: Actas V Congreso Mundial del Aguacate, Granada- Málaga, España. 1924 Octubre. p. 155 - 160.

Ciren. 1985. Descripciones de suelo. V región. Publicación $\mathrm{N}^{\mathrm{o}}$ 50. Centro de Información de Recursos Naturales (Ciren). Santiago, Chile. $317 \mathrm{pp}$.
Ciren-Corfo. 1989. Frutales menores y de hoja persistente. Requerimientos de clima y suelo. Centro de Información de Recursos Naturales (Ciren), Corporación de Fomento de la Producción (Corfo). Santiago, Chile. 65 pp.

Collier R.L., and E.C. Turnblom. 2001. Epicormic branching on pruned coastal Douglas fir. West. J. Appl. For. 16:80-86.

Deal R.L., R.J. Barbour, M.H. McClellan, and D.L. Parry. 2003. Development of epicormic sprouts in Sitka spruce following thinning and pruning in southeast Alaska. Forestry 76:401-412.

Durand, B. 1990. Clonal propagation of avocado rootstocks. Farming in South Africa, Avocados DS.

Gil-Albert, F. 1992. Tratado de arboricultura frutal. La ecología del árbol frutal. $3^{\mathrm{a}}$ ed. Mundi-Prensa. Madrid, España. 248 pp.

González, H., B. Llano, and S. Salazar. 1990. Effect of IBA, and benzil amino purine on the germination, shoot development, and root formation in avocado embryos cultivated in vitro. California Avocado Society Yearbook 74:201-205.

Gordon, D., A. Rosati, C. Damiano, and T.M. Dejong. 2006. Seasonal effects of light exposure, temperature, trunk growth and plant carbohydrate status on the initiation and growth of epicormic shoots in Prunus persica. Journal of Horticultural Science \& Biotechnology 81:421-428.

Pernice, F, L. Solari, and T.M. Dejong. 2006. Comparison of growth potentials of epicormic shoots of nectarine trees grown on size-controlling and vigorous rootstocks. Journal of Horticultural Science \& Biotechnology 81:211-218.

Pliego-Alfaro, F., C. López-Encina, and A. BarcelóMuñoz. 1987. Propagation of avocado rootstocks 
by tissue culture. South African Avocado Grower's Association Yearbook 10: 36-39.

Smith, D., J. Köhne, and J. Schutte. 1993. Progress with the single tree management concept. South African Avocado Grower's Association Yearbook 15:80-81.

Taiz, L., and E. Zeiger. 1998. Plant Physiology. 2nd edition. Sinauer Associates Inc. Publishers, Sunderland. 792 pp.

Tapia, P. 1993. Aproximación al ciclo fenológico del aguacate (Persea americana Mill.) cv. 'Hass', para la zona de Quillota, V región. Taller de Licenciatura Agr. Pontificia Universidad Católica de Valparaíso. Facultad de Agronomía. Quillota, Chile. 141 pp.
Takiya. M., H. Koyama, and K. Umeki. 2010. The effects of early and intense pruning on light penetration, tree growth, and epicormic shoot dynamics in a young hybrid larch stand. Journal of Forest Research 15: 149-160.

Whiley, A. 2002. Crop management. In: The avocado. Botany, production and uses. Whiley, A., B. Schaffer and B. Wostenholme (ed.). Cabi publishing. Wallingdorf. p. 231-258.

Zimmermann M.H., and C.L. Brown. 1971. Trees structure and function. New York. Springer-Verlag. 336 pp. 